\title{
UNIFIED TREATMENT OF COMPLEMENTED SCHWARZ AND GRÜSS INEQUALITIES IN INNER PRODUCT SPACES
}

\author{
Neven Elezović, LJUbo MaRAngunić AND Josip PeČARIĆ
}

\begin{abstract}
There is a lots of known complemented Cauchy-Bunyakowsky-Schwarz' inequalities in the literature. In the first part of this paper we shall deduce many of them using very simple technique of inner product space. The similar technique is applied in the second part to complemented Grüss' inequality.
\end{abstract}

Mathematics subject classification (2000): 26D15.

Key words and phrases: Schwarz inequality, Grüss inequality, inner product.

\section{REFERENCES}

[1] J. B. DiaZ, F. T. MetCalf, Stronger forms of a class of inequalities of G. Pólya/G. Szegö and L. V. Kantorovich, Bull. Amer. Math. Soc. 69 (1963), 415-418.

[2] S. S. Dragomir, Some Grüss' type inequalities in inner product spaces spaces, J. Ineq. Pure \& Appl. Math. 4 (2003), No 2, Article 42.

[3] S. S. DRAGOMIR, A counterpart of Schwarz inequality in inner product spaces, RGMIA Res. Rep. Coll. 6 (2003), Suppl. Article 18.

[4] S. S. DRAGOMIR, Some companions of Grüss inequality in inner product spaces, RGMIA Res. Rep. Coll. 6 (2003), Suppl. Article 8.

[5] S. S. DRAGOMIR, Reverses of Schwarz, triangle and Bessel inequalities in inner product spaces, RGMIA Res. Rep. Coll. 6 (2003), Suppl. Article 19.

[6] W. Greub, W. RheinBoldt, On a generalization of an inequality of L. V. kantorovich, Proc. Amer. Math. Soc. 10 (1959), 407-415.

[7] M. S. Klamkin, R. G. McLenaghan, An ellipse inequality, Math. Mag. 50 (1977), 261-263.

[8] G. PóLYA, G. SzeGÖ, Aufgaben und Lehrsätze aus der Analzsis, Vol. 1, Berlin 1925, pp. 57 and 213-214.

[9] O. ShISHA, B. Mond, Bounds on differences of means, Inequalities I, New York-London, 1967, pp. 293-308.

[10] NENAD UJEVIĆ, A new generalization of Grüss inequality in inner product spaces, Math. Inequal. \& Appl. 6 (2003), 617-623.

[11] G. S. WATSON, Serial correlation in regression analysis I, Biometrika 52 (1955), 322-342. 